\title{
Organizational Evolution and Disciplinary Transition: Case of a R\&D Public Center in Mexico
}

\author{
Vega-González Luis Roberto \\ Centro de Ciencias Aplicadas y Desarrollo Tecnológico \\ Universidad Nacional Autónoma de México, Circuito Exterior S/N \\ Ciudad Universitaria, A.P. 70-186, Delegación Coyoacán, CP 04510, México \\ Tel: 5622-8602 ext. 1135 E-mail: lrvg@unam.mx
}

Received: July 19, 2017 Accepted: August 4, 2017

doi:10.5296/ber.v7i2.11564 URL: https://doi.org/10.5296/ber.v7i2.11564

\begin{abstract}
In this work, we present the case of the Applied Sciences and Technology Development Center (CCADET, from its Spanish acronym) of the National Autonomous University of México, to show that there is a close relation between the organizational evolution and the disciplinary transition in organizations that perform research and development (R\&D). The methodology used, was the division of the time life span of the center in decades to later proceed with the identification of representative projects developed during the different stages of its life. Emphasis was placed in documenting the various disciplines dominated by the individuals that conformed the intellectual capital resources required to accomplish the projects. Relating this information it was possible to identify the disciplinary transition (DT) that have occurred along the evolution of the organization.

The awareness of the $D T$ suffered by the organization and of its actual capacities is essential for organizational knowledge management and its appropriate conduction in concordance to its strategic development plans.
\end{abstract}

Keywords: Disciplinary transition, Multidisciplinary and trans-disciplinary projects, R\&D centers evolution

\section{Introduction}

As living beings, an organization born, grows and gets transformed over time. The objective of Research and Development (R\&D) organizations is the generation of knowledge in various forms. As time passes by, they increment their capacities and become more complex inasmuch as the disciplines dominated by the organization's personnel collaborating in 


\section{$\triangle$ Macrothink}

projects are diverse.

The scientific knowledge and the technology developed in the Faculties, Institutes and R\&D Centers of the Universidad Nacional Autónoma de México (UNAM, from its Spanish acronym), have proven to be of great importance to society.

Likewise, through their specializations, master and doctorate programs, high level human resources are prepared, that once finishing their education get incorporated to the country's productive sectors and to other public or private research institutions.

In Mexico, many of the Institutes and Research Centers are monodisciplinary, they only cultivate a basic discipline and just a few entities are multidisciplinary as the Centro de Física Aplicada y Tecnología Avanzada (CFATA) located in the city of Queretaro and the Centro de Ciencias Aplicadas y Desarrollo Tecnológico (CCADET) located in the University City campus south Mexico City.

By means of a case study, the objective of this work is to demonstrate the hypothesis that there is a close relationship between the organizational evolution and the disciplinary transition of a public R\&D center. Methodology is based on the selection of representative projects developed at the CCADET, through the different phases of its organizational growth and maturity and the identification of the different discipline types that were required to carry them out.

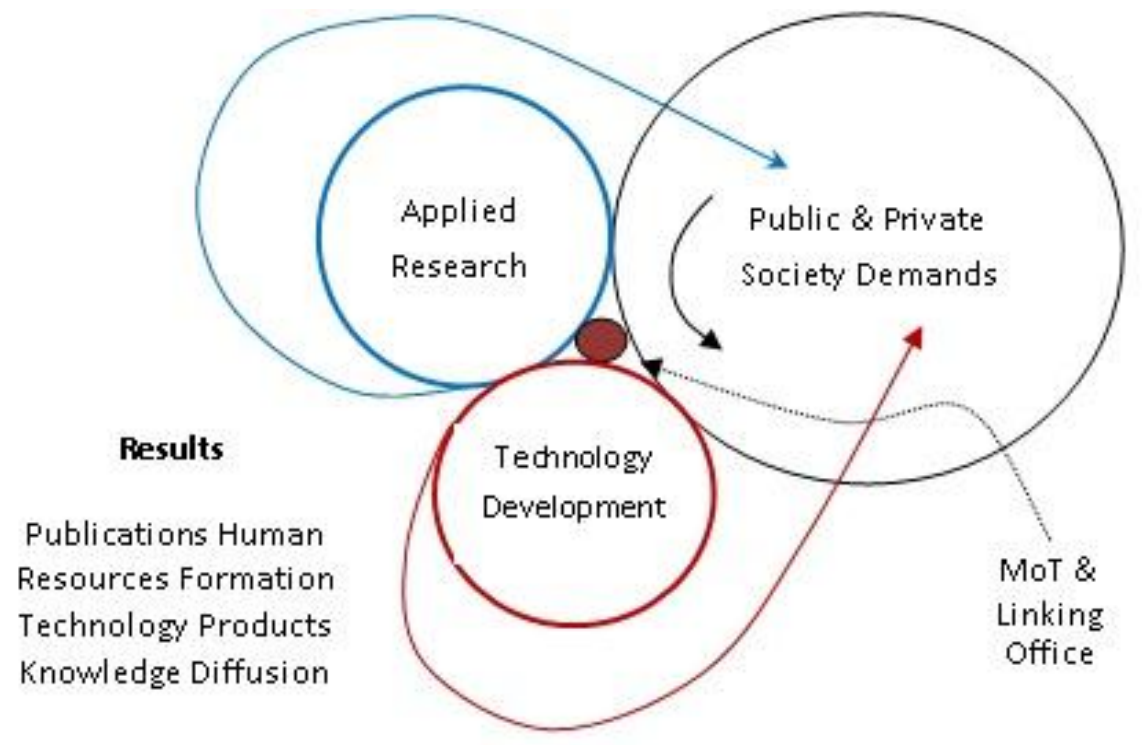

Figure 1. The CCADET's linking process

In its 46 years of existence the CCADET has been converted in a mature organization that has contributed with society through the results of the projects performed for different public and/or private institutions with which it has been linked. Figure 1 shows the Center's linking process and the products it deliver to society.

Over the years, the intellectual capital and research infrastructure of the center grew by producing its organizational evolution. Each year, the central administration of UNAM 
invested in physical and experimental infrastructure and in the recruitment and integration of researchers and technologists who have been growing academically along the organization's life.

A meaningful part of the investigation infrastructure has been obtained with economic resources obtained via externally contracted projects. Furthermore, the authorities and some academics from the Center have submitted proposals for the Funds for Infrastructure Strengthening of the Consejo Nacional de Ciencia y Tecnología. (CONACYT, 2017).

Experience has shown that in order to generate knowledge and to offer integrated solutions to society, when realizing $\mathrm{R} \& \mathrm{D}$, the starting point is the organization's academic groups capacity to establish multidisciplinary and interdisciplinary teams to develop projects directed to obtain technological solutions for external organizations' demands. In those projects the generated knowledge were both, internalized and externalized.

The first methodology step used to demonstrate the hypothesis suggested was, the division of the center's lifetime in different evolutionary stages identifying those important events occurred along its lifetime. Next step, was the revision of the center's annual informs, internal regulations and other proper documentation such as signed contracts and collaboration agreements when they were available. Later, using Groenveld (1997) methodology there came the identification of the most relevant projects developed with external financing, in each evolutionary stage, according with their social and/or economic impact.

Afterwards, we investigate the data of the disciplines dominated by the different academics of the teams who developed each project, the configuration of the project team, its features and the specific knowledge generated.

Although that we studied projects developed along the diverse evolutionary stages of the center, emphasis was placed in technology development projects realized from 2001 to 2015. The data registered for each project were the project specifications and the technologic solutions requested, the groups and academics participating, its location within the organizational structure, the year performed, the technologic products generated, the amount and origin of the financing, intellectual property obtained and the social or economic impact obtained. Finally results were integrated showing the way disciplinary schemes were used to build the center's knowledge along its organizational life.

\section{Theoretical Framework}

\subsection{Capacities, Competences and Knowledge}

First consideration was, that beyond the disciplines dominated by the center's departments, its global competence is mainly determined by the abilities, capacities and knowledge of the individual academics that integrate the different R\&D groups, who, through the years have jointly participated in the development of contracted projects. Through the years, the manifestation of this knowledge gets evident in the organization. This is the way of how the organization matures and develops critical competences. (Prahalad and Hamel, 1990). 
Beyond the external incomes obtained for the technological products delivered to the counterparts of financed projects, main result is the generated and internalized knowledge. This is very important because it occurs, when realizing financed projects, knowledge is generated, internalized and diffused within the whole organization. (Nonaka and Takeuchi, 1999).

\subsection{Discipline Concepts and Theories}

The root of the word "discipline" appeared with the universities of XII Century. Later, with the specializations arrival, the duality subject-object materialized under the discipline concept in France at the end of XIX century. According to Peñuelas (2005) the discipline and the non-discipline are two complementary boarding processes for the construction of study objects, the solution of concrete problems and the diverse reality form discourses.

Morin (1996) established discipline as an organizational category within the scientific knowledge that comprehends the division and specialization of the diverse science domains. Its tendency is toward autonomy, borders delimitation and to elaborate its own language, techniques and eventually its own theory. (Luengo, 2012).

Nevertheless, with the evolution of science, disciplinary borders get broken, producing the circulation of problems from one to other disciplines, and the migration of concepts, resulting in the formation of new hybrid disciplines (psychophysiology, neurochemistry, sociobiology, and so), the emergence of cognitive reorganization schemes, as ecology, cybernetics or space sciences. In that sense, the disciplines history is also the interdisciplinary and trans-multi-disciplinary history. (Morin, 2000). Disciplines are necessarily and intellectually justified with the condition to acknowledge the interdependences existence among distinct sciences.

The multi or pluri-discipline is used to study an object by means of the conjunction of several disciplines, enriching the understanding about it; nonetheless, each participant discipline conserves its own limits. The sum of the knowledge used is the main factor to the better understanding of each object under study. (Nicolescu, 2000).

The interdiscipline consists in the reciprocal relation among disciplines working to solve the same problem, situation or concrete phenomenon. Ultimately implies the transference of methods from one discipline to the other, as well as information exchange and collaboration between theoretical and practical knowledge from different disciplines.

The inter-discipline is necessary for the resolution of concrete problems, it is normally realized through teams work because it requires the contributions of people coming from different science fields. According to Follari (2005), the individual inter-discipline does not exist.

Sarquís and Buganza (2009) noted that in his manifest, Nicolescu (2009) indicated that the inter-discipline can be understood via its applications. For example, it happens when methods of nuclear medicine are transferred to medicine. At simple didactic level, the emergence of a new discipline happens because the previous interaction of other disciplines. Peñuelas (2005, 
p. 53). In that sense, the emergence of the biomedical medicine came from the interaction of the biology, the medicine and the engineering.

\subsubsection{Trans-discipline}

The "trans" term means beyond. For Piaget (cited by Nicolescu, 2006; Motta, 2002, p.3), trans-discipline is the sum of interactions and reciprocity between knowledge and specialized research across the disciplines acting within a system with no borders among them. A trans-disciplinary collaborative approximation among science, technology and society, can be realized when there are no borders among them.

The trans-discipline is also a meta-concept, focused to the solution of highly complex trans-sectorial problems, for example the regional sustainability problem. In those cases, an essential requirement is the linking among the moral, practical, technical, pragmatic and institutional knowledge.

For De Vos Malan, J., (2015), if the multi-disciplinary investigation can be described as "additive", and the inter-disciplinary work as "interactive", then the trans-disciplinary work can be characterized as holistic, besides, the trans-disciplinary focus used to perform projects, requires of a careful preparation and the readiness to understand the language and the fundamental philosophies of the disciplines dominated by the different participant colleagues. (Galliers, 2004).

The trans-disciplinary investigation is also characterized for the participation of researchers and stakeholders who are experts in different disciplinary fields. The trans-disciplinary projects can also be used to form university students through the use of tools as the systemic approach and the learning based on problems. (Gray et al., 2014).

Another important aspect is the wide research themes diversity that can be realized using a trans-disciplinary approach. For example, De Vos Malan, J., (Op. cit.) points out that through the use of a common conceptual model to link the theoretical frameworks of diverse disciplines, Australian trans-disciplinary research teams have realized projects in themes and fields as diverse as cultural diplomacy, economic competitiveness and shale gas production.

Meanwhile, Vandermeulen and Van Huylenbroeck (2008) mention that lately, some sustainable development agricultural projects are being developed in Belgium, in which they are using discussion software platforms where researchers from different disciplines like economists, ecologists, social scientists and geographers, provide and share specific knowledge useful for the project.

Sauvé et al., (2016) mentions that the combination of natural sciences, social sciences, and the engineering and management disciplines is becoming essential to face current challenges of environment care; nevertheless, this can be a complex task, because experts from different disciplines can conceptualize problems in different ways; furthermore, sometimes their vocabularies cannot be understood for others. De Vos Malan, J., (2013), has found that in practice, trans- disciplinary project administrators can help for the success of interdisciplinary research projects 
Another complex research field that requires trans-disciplinary treatment is the risk management engineering that requires an understanding of social, political, economic, engineering, technical, administrative and communication aspects. (Le Coze, et al., 2006). Research and development projects for the health sector can be multidisciplinary but when they are related to sicknesses with high deaths and morbidity indexes, they must be treated in a trans-disciplinary way, because require both the establishment of multidisciplinary collaborations between investigators and clinic people as well as wider collaborations with other non-academic groups as industrial partners, community groups and institutional politics developers. (Polyak, 2014).

Research and development projects for health can also be multidisciplinary. Korb et al., (2015) mention that the development of medical technologies requires the participation of different scientific and technical fields as surgery, electrical, mechanical and computational engineering and the participation of auxiliary personnel for patients management. The challenge is to achieve the agreement among the professionals of different cultures involved in the projects, which is not an easy task.

Hagoel and Kalekin-Fishman (2002), stress the importance of research into new disciplines to understand how they appear, how they are institutionalized and how they change over time. This usually results in changing paradigms in social sciences, natural sciences and the humanities.

It is natural that in projects where many actors are involved and work with such diverse topics, many data and knowledge are produced, so it is essential organize the information. Thus, in his work on integration of knowledge, Defila and Di Giulio (2015), point that given the fact that the inter- and trans-disciplinary research are contributions from different disciplinary experts and other stakeholders, synthesis turns out to be one of the problems crucial for integrating the results thereof.

In next section we will see that many of the technology developed by the CCADET in recent decades were developed as multidisciplinary and interdisciplinary research and supplied to important public organizations with high social impact. Nowadays R\&D projects are beginning to be transdisciplinary.

\section{CCADET's Organizational Evolution}

In this section we will present the Center's historical evolution indicating some relevant projects performed through the years and the disciplines and interactions of the human resources required to carry them out.

The Instruments Center of the National Autonomous University of Mexico, was founded on December 15, 1971, by Pablo Gonzalez Casanova, to respond to the need to solve the problems of scientific and educational instrumentation at UNAM. The Centre was seconded to the Coordination of Scientific Research and was assigned with 7 main functions according to 1997 Institutional Report. Their functions were:1) Their functions were:1) To design and build equipment and teaching materials on request of UNAM's schools, colleges, institutes and centers. 
2) Collaborate with the different university entities in performing designs.

3) Promote the instrumentation developed at the UNAM to outside organizations, carrying out detailed studies on the feasibility of producing scientific and technical equipment on an industrial scale.

4) Promote the necessary patents to protect the interests of the UNAM.

5) Collaborate with the faculties, schools, colleges and the College of Sciences and Humanities in establishing the needs, laboratories designs, equipment and instruments, and in the construction of these.

6) To assist university departments on issues related to maintenance of scientific equipment.

7) Work closely with research groups on science education.

Between 1972 and 1973, the CCADET conducted the inventory of the scientific equipment of the UNAM, with the sponsorship of CONACYT, evaluated the investment made by the institution, and the status and use of equipment; it also developed a schedule of maintenance and repair of instruments and equipment to optimize their use and avoid their duplication thus achieving significant cost savings.

During this period, the services of information and technical advice to the university community were established. These helped the institution academics in the selection and acquisition of equipment of the best rated brands and models.

Comparing the requests for new equipment with existing inventory using UNAM's records allowed to determine when a new equipment needed to be purchased and to make recommendations for its best use.

Later, the Center added maintenance service in order to support the UNAM's own needs, then specialized groups were formed in electronic equipment and mechanical production.

In 1974, the Center occupied its facilities in the external circuit of the University campus, located by the side of the General Directorate of Academic Computing Services (Centro de Instrumentos, 1988).

In its first seven years the Center provided maintenance support for the equipment of other university entities that performed scientific and humanistic research, these activities permitted avoiding to buy expensive equipment twice and promoting the optimal use of them with less wasted time. Center personnel promoted maximum exploitation of costly equipment before the acquisition of new ones, especially in the case of electronic and scanning microscopes, like so other high cost instruments. The Center also provided equipment design and consulting.

In 1979 was created the Engineering Department that later became the Experimental Science Teaching Department. In 1981 the Applied Acoustics Laboratory was founded (Centro de Instrumentos, 1988).

In 1982 the Center structured its strategic plan around the preventive and corrective 
maintenance services, the design and development of instrumentation for the areas of biotechnology, biomedical, acoustics, optoelectronics, microcomputers and instruments for oceanographic research, telescopes building, the design and construction of equipment for the experimental physics teaching and scientific and didactic equipment for the investigation and teaching performed by several other university dependences (Centro de Instrumentos, 1983).

Same year the Center installed the satellite signals receptor portable station SATCOM III-R, which broadcast some television foreign advertising to show the academic community the benefits of satellite communication, besides, the first computer designed by the Center was presented.

In 1984 was created the Metrology Section and one of its first projects was the design and construction of a three coordinates machine. In 1987 the computer equipment maintenance section and the acoustics research group were created.

In April 2002 the Technical Council of the Scientific Research University's Subsystem approved the name change of the institution to Center for Applied Science and Technological Development. The Center passed from being a Service Center to be a Research Center. Today's mission is the realization of R\&D to contribute with the solving of society specific problems. In 2002 also occurred the first linking with the Cardiology National Institute (INC, from its Spanish acronym). The INC asked for the University help with diverse projects related with the manufacturing of cardiac valves.

With economic resources provided by the National Council for Science and Technology (CONACYT, from its Spanish acronym) for this project, a cardiac valve tester and a machine for seal and assembly of the rings for the bio prostheses were obtained. This project was a notable interdisciplinary project, because academics from the Laboratories of Micromechanics, Electronics and the Prototypes Section collaborated in it.

A second project developed also for the INC in 2004, with funds coming also from CONACYT, was an "Automatic laser cutter for bovine pericardium". It consisted of an optical CO2 laser mounting and an X-Y movements controlled stage. Once again interdisciplinary work of the groups of Non Linear Optics and Micromechanics was required to develop this project.

In 2008 after extraordinary negotiation efforts of the Center's Director, the head of the Linking and Management of Technology and some academics, an important Collaboration Agreement was signed with the Science and Technology Mexico City Institute (ICyTDF, from its Spanish acronym). The objective of this agreement was the realization of five R\&D projects related to mammary cancer (MaCa). This sickness was declared to be an epidemiologic emergency in the City of Mexico in 2006. Projects included were (a) Computer assistance system for the MaCa diagnostics, (b) mammary tomography system based on photo thermal techniques, (c) objects detection in dense media for mammographic applications, (d) statistical methods for epidemiologic investigations, (e) mobile unit for the mounting and transfer of a digital mammography machine.

Once again, to carry on the projects a multiple and inter-disciplinary approach was required, 
so an important number of academics and academic groups of all the Center Departments participated, among others: Optics, Prototypes Section, Visualization and Images, Sensors, Acoustics, Electronics, Process Modelling and Simulation.

A further phenomenon that occurred naturally was the signing of cooperation agreements with ICyTDF for developing more than 28 projects in the area of health and environment during the years 2009 to 2011 . Most of them required a multidisciplinary approach to be accomplished.

At the end of 2012 a Collaboration Agreement was signed for establishing a new Research and Development Unit (UIDT, from its Spanish acronym) at downtown Mexico's City General Hospital. Today the UIDT has $80 \mathrm{~m} 2$ and probably be expanded to $150 \mathrm{~m} 2$ at the end of 2017. There are three academics assigned to the UIDT, with doctorates in the areas of physics and computer engineering, working there permanently with a dozen of students.

The central idea was to offer the Hospital's different service areas the Center's capacities for developing diagnostic systems, instruments, while the Hospital provided the supervised access to patients.

Some of the Unit's projects approved by Hospital's medical committees are the following:

- Skull and maxillofacial prosthesis developed with polymethyl methacrylate (PMMA) with scanning and printing techniques 3D

- Prostate surgery simulator for training Urologists surgeons

- Functional Thermography for diabetic foot diagnostics

- Heat transfer studies for determination of liver tissue thickening parameters

- Photo acoustic tomography for breast cancer (BC) detection.

\subsection{Discussion}

With 46 years of existence CCADET is now a public R\&D complex organization with the participation of over 125 different professionals with complementary experience levels realizing projects in diverse areas. They all have academic specializations, masters and doctorates in various fields of physics, engineering, chemistry, education and industrial design, among others. In the Center also participate over two hundred students making their masters and doctorates, and about a hundred people in other supporting areas.

Unlike a company that produces goods and services, the Center's central purpose is the generation of knowledge and its application to the development of technology.

Its linking strategy has been very clear, both research and technological development areas direct their efforts to the development of projects that provide technology solutions to external organizations that contract or agree projects for technology development.

The academic goals of the staff match with the objectives of the technology development projects pursuing to solving societal problems and to improve the competitiveness of organizations that request technology. In some cases reverse engineering is performed to improve and develop appropriate technology. The organization is structured in the following 
four departments: Instrumentation and Measurement, Techno-sciences, Microwaves and Optics and Information Technologies.

The four CCADET's Departments cultivate different knowledge areas. This is a strength when the time comes to work in a common project. Therefore, because of the diversity of disciplines of the Centre members, when they get grouped in Departments, automatically inter and multi discipline is produced.

On the other side, relations with high social impact external organizations as the General Hospital of downtown México City and the south city General Hospital Manuel Gea González are profiling high impact Trans - disciplinary projects, this in accordance with Cardoso (1999) and Rojas (2010) who mention, public health tasks require interdisciplinary and inter sectorial focus.

The R\&D projects developed by the Center academics, contracted with external public and private organizations, have shown that the main application areas of the center are: Health, Education, Science and Technology, Energy, Environment and Industry. The notable differences in this application areas confirm that R\&D work is in essence multi and interdisciplinary.

\section{Identification of Center Stages in Relation with Projects and Disciplinary Activity}

\subsection{First Stage}

Time period: 1971 to 1991

Important organization events: Centers creation (1971), creation and operation of the Maintenance Units and of the Engineering Department (1979).

Relevant Projects: didactic prototypes development for elemental and secondary schools, germinator and fermenter laboratory equipment and electrophoresis chambers.

Intellectual Capital: electronic and mechanical engineers, industrial designers, physics, technical personnel.

Disciplinary activity: technical background mainly unidisciplinary.

\subsection{Second Stage}

Time period: 1991 a 2002

Important organization events: the recruitment of the first researchers of the Centre in the areas of acoustics and optics, in 1996 the organization got transformed from an administrative institution to an R\&D organization. CCADET became a member of the Academic Council of the Physics and Mathematics and Engineering.

Relevant Projects: digital dynamometer, ionization antenna and screw pump.

Intellectual Capital: Doctors (PhD's) in Physics and Chemistry with different specialties, electronics engineers, mechanical engineers, industrial designers, some physicists and technicians. 


\section{MInstitute ${ }^{\text {Macrothink }}$}

Disciplinary activity: majorly multidisciplinary

\subsection{Third Stage}

Time Period: 2002 a 2011

Important organization events: in 2004 the institution changes its name from Instruments Center to Applied Sciences and Technology Development Center. The Linking and Technology Management Office and the Intellectual property Unit were created. They began writing and submitting records of patents, trademarks and copyrights.

Relevant Projects: Center personnel developed software systems, instruments for medical diagnostics, a low weight solar concentrator, didactic equipment for science teaching in elementary, secondary, and high schools, intelligent systems to predict plague and sickness of plants and crops of the Michoacán Mexico's State., a cardiac valve tester, a machine for sealing bio-prostheses rings, an automatic laser system for cutting bovine pericardium for cardiac bio prostheses manufacturing and a photo acoustics tomography system, among others.

Intellectual Capital: Physics, Chemistry and Engineering doctors with different specialties, electronic, electric, mechanic engineers, industrial designers, some physicists and technicians.

Disciplinary activity: multidisciplinary and interdisciplinary.

\subsection{Fourth Stage}

Time Period: 2011 a 2016

Important organization events: The Research and Technological Development Unit (UIDT, from its Spanish acronym) at the General Hospital of México located downtown, was created in 2012. Besides, in October 2015 it was signed the agreement for the creation of the Unit for Technological Development at General Hospital Manuel Gea González, located south city.

Important projects: functional thermography for diagnosis of diabetic foot, cranial and maxillo facial prostheses developed in polymethyl methacrylate (PMMA) with 3D scanning and printing techniques, development of a vitamin supplement based on the emulsion of nopal mucilage added with leguminous flour vitamins, for post-operated bariatric surgery.

Intellectual capital: Doctors in Physics, Chemistry and Engineering doctors with different specialties, electronic, electric, mechanic engineers, industrial designers, some physicists and technicians, collaboration with different specialties physicians, nutritionists, ophthalmologists, urologists, orthopaedists, among others, working for different hospitals.

Disciplinary activity: multidisciplinary and interdisciplinary and beginning the transdisciplinarity. 


\section{Results}

We can observe the disciplinary transition curve, in Figure 3

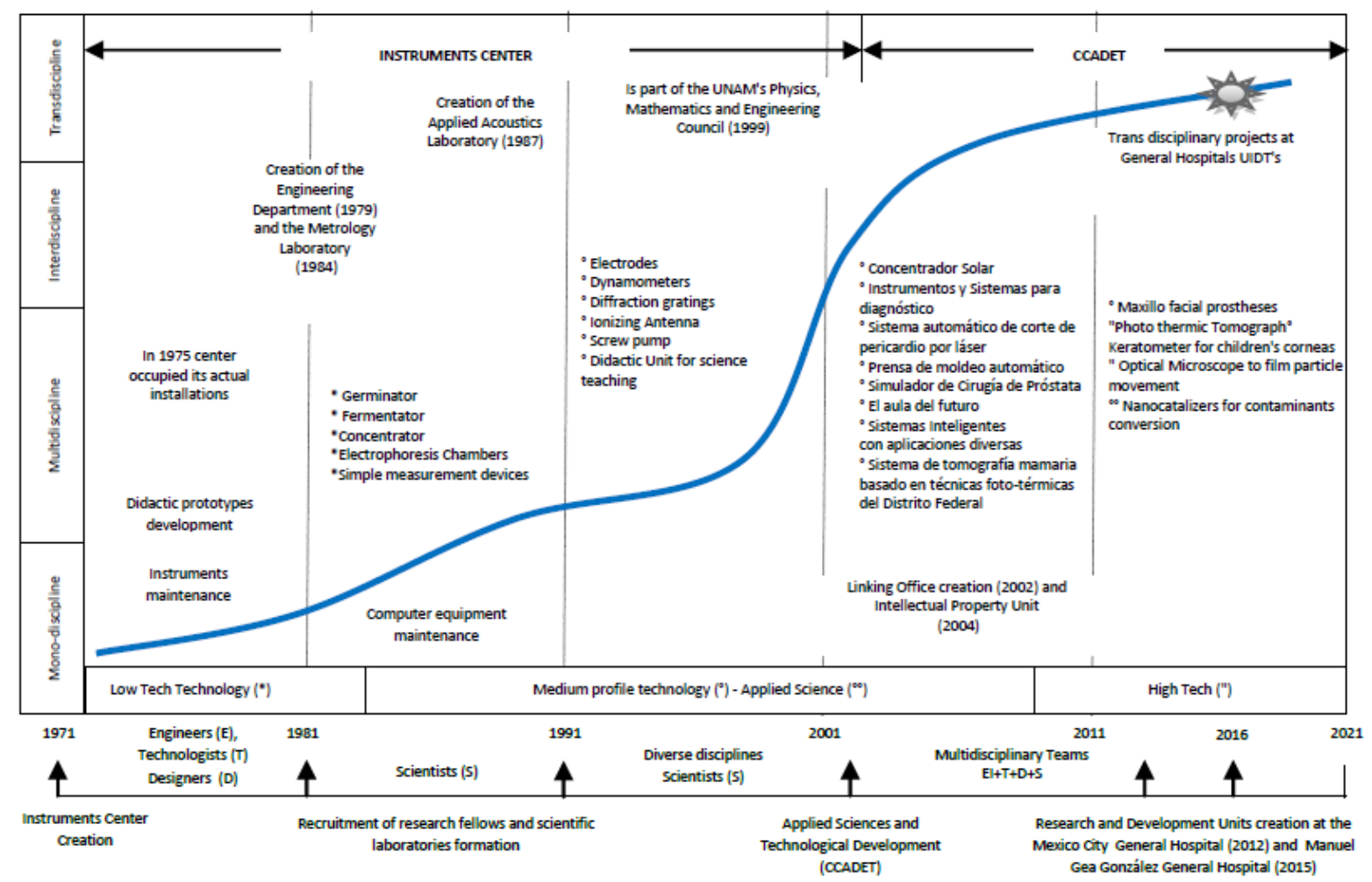

Figure 3. Graphics of the CCADET's organizational evolution in terms of its disciplinary transition

\section{Conclusion}

Through the growth of the R\&D center studied, it can be seen that nor just its academic personnel and infrastructure were incremented, but also the skills and competitiveness of their intellectual capital, generating knowledge in an expanding spiral driven by the development of externally financed projects. With the methodology used in this paper, it was shown that knowledge construction and the complexity of the projects undertaken is directly related with the use of multiple disciplines fostered the organization's disciplinary transition.

In its early years the center was able to develop simple devices for its own use or that of other university entities, to carry them out it only was required one-disciplinary work. At the middle of the center's life, it got linked with external public organizations, developing more complex technology and solutions that required interdisciplinary work. In the third stage of its life, the center got linked with external institutions of other sectors that faced important and complex social problems for which it was necessary to establish trans-disciplinary large scale projects of greater social and economic impact.

The acquisition of trans-disciplinary collaboration capacities has required the construction of a generous organizational culture, through which knowledge is socialized in the search for a superior good, making contributions of technological knowledge that had could contribute to 
the solution of social problems.

However, it is surprising that it is sometimes easier for academics to collaborate with academic staff from other disciplines and other university bodies or from other institutions than to collaborate with academics from the same institution.

Nevertheless, taking advantage of this phenomenon it is possible to generate a virtuous circle, allowing the development of new projects and the construction of new competencies, in the organization.

In the last decade analyzed, it was observed that in the development of projects for the health sector, several academic groups of the center have contributed, producing systems, technological devices and diagnostic instrumentation. This result is not surprising since CCADET was created as a center for developing instruments. Consistently, in this research we found that those projects that have led to greater knowledge development in the different participating academic groups, have been related to the development of instruments in one form or another.

\section{References}

Cardoso G. M. A., (1999). Interdisciplina o multidisciplina en el área de la salud. Nueva Época Salud Problema. 4(7), 31-37.

Centro de Instrumentos. (1980). Memoria Descriptiva de Instalaciones Físicas en la Universidad Nacional Autónoma de México (UNAM).

Centro de Instrumentos. (1980). Informe Anual: Organización, Universidad Nacional Autónoma de México (UNAM).

Centro de Instrumentos. (1981). Informe Anual de Actividades Coordinación de la Investigación Científica, (UNAM).

Centro de Instrumentos. (1983). Informe Anual de Actividades Coordinación de la Investigación Científica, (UNAM).

Centro de Instrumentos. (1988). Informe Anual de Actividades. Coordinación de la Investigación Científica, Universidad Nacional Autónoma de México (UNAM).

Centro de Instrumentos. (2001). Informe de Actividades 1998-2001. Dr. Lara Rosano Felipe. Coordinación de la Investigación Científica, Universidad Nacional Autónoma de México (UNAM).

Centro de Instrumentos. (2001). Informe de Actividades 2001-2005. Dr. Lara Rosano Felipe. Coordinación de la Investigación Científica, Universidad Nacional Autónoma de México (UNAM).

Centro de Instrumentos. (2014). Informe de Actividades 2006-2014. Dr. José Manuel Saniger Blesa. Coordinación de la Investigación Científica, Universidad Nacional Autónoma de México (UNAM). 
CONACYT (2017). Consejo Nacional de Ciencia y Tecnología. Available at: https://www.conacyt.gob.mx

De Vos Malan, J., (2013). Collaboration, Knowledge \& the Transdisciplinary Manager: Helping interdisciplinary research projects to flourish. Proceedings - 1st Annual International Interdisciplinary Conference, AIIC 2013, 24-26 April, Azores, Portugal.

De Vos Malan, J., (2015). Exploring Challenges of Transdisciplinary Research: an Australian Case Study. European Scientific Journal, 1(1), 434-459.

Defila, R., Di Giulio, A., (2015). Integrating knowledge: Challenges raised by the "Inventory of Synthesis". Futures. 65, 123-135. https://doi.org/10.1016/j.futures.2014.10.013

Follari, R., (2005). La interdisciplina revisitada. Andamios. 1(2), 7-17.

Galliers, R. D., (2004).Trans-disciplinary research in information systems. International Journal of Information Management, 24(1), 99-106.

https://doi.org/10.1016/j.ijinfomgt.2003.09.012

Gray, J., Williams, J., Hagare, P., Abby, Mellick, L. A., \& Sankaran, S. (2014). Lessons Learnt from Educating University Students through a Trans-Disciplinary Project for Sustainable Sanitation Using a Systems Approach and Problem-Based Learning. Systems. 2(1), 243-272. https://doi.org/10.3390/systems2030243

Groenveld, P., (1997). Roadmapping integrates business and technology. Research Technology Management, 40(5), 48-63.

Hagoel, L., Kalekin-Fishman, D., (2002). Crossing Borders: Toward a trans-disciplinary scientific identity. Studies in Higher Education, 27(3), 297-308.

https://doi.org/10.1080/03075070220000680

Korb, W., Geißler, N., Strauß, G., (2015). Solving challenges in inter- and trans-disciplinary working teams: Lessons from the surgical technology field. Artificial Intelligence in Medicine. 63(1), 209-219. https://doi.org/10.1016/j.artmed.2015.02.001

Le Coze, J. C., Salvi, O., \& Gaston, D., (2006). Complexity and Multi, Inter or Trans-Disciplinary Sciences: Which Job for Engineers in Risk Management? Journal of Risk Research, 9(5), 569-582. https://doi.org/10.1080/13669870600717541

Luengo G. E., (2012). Interdisciplina y transdisciplina: aportes desde la investigación y la intervención social universitaria. ITESO, Guadalajara Jalisco. Available at:

https://formacionsocial.iteso.mx/documents/10901/0/D-200400-2.pdf/c25c322f-fd1e-47bf-be $55-f a 427 f 2 c d a 6 a$

Morin, Edgar, (1996). Sobre la interdisciplinariedad, Sociología y Política. Departamento de Ciencias Sociales y Políticas, Universidad Iberoamericana, Nueva Época, 8.

Morin, Edgar, (2000). La mente bien ordenada: pensar la reforma, pensar el pensamiento, Barcelona, Seix Barral. 


\section{Macrothink}

Business and Economic Research ISSN 2162-4860 2017, Vol. 7, No. 2

Motta, R., (2002). Complejidad, educación y transdisciplinariedad. Polis, Revista de la Universidad Bolivariana, Universidad de Los Lagos Santiago, Chile, 1(3), 1-21.

Nicolescu B. (2000) Transdisciplinarity and complexity: Levels of reality as source of indeterminacy. Bulletin Interactif du Centre International de Recherches et Études Transdisciplinaires. Available at: http://nicol.club.fr/ciret/bulletin/b15/b15c4.htm

Nicolescu, B., (2006). Transdiciplinariedad: Pasado, Presente y Futuro, 1a Parte. Visión Docente Con-ciencia, $V(31)$, Available at:

http://www.ceuarkos.com/Vision_docente/revista31/t3.htm

Nicolescu, B., (2009). La transdisciplinariedad, Multiversidad. Mundo Real, Ed. Edgar Morin, México.

Nonaka I., Takeuchi H., (1999). La organización creadora del conocimiento, cómo las compañías japonesas crean la dinámica de la innovación. Ed. Oxford.

Peñuelas, V. L. A., (2005). la transdisciplinariedad, más allá de los conceptos, la dialéctica. Andamios. 1(2), 43-77.

Polyak, SW., (2014). Antibiotic Resistance in the Indigenous Australian Population: Combating the Problem through Trans-disciplinary Research. Journal of Medical Microbiology \& Diagnosis. 3(5). https://doi.org/10.4172/2161-0703.1000162

Prahalad, C., \& Hamel, G. (1990). The Core Competence of the Corporation, Harvard Business Review, 68(3), 79-91.

Rojas O. F., (2010). Interdisciplina e Intersectorialidad. Revista Cubana de Salud Pública; 36(3), 197-200. https://doi.org/10.1590/S0864-34662010000300001

Sarquís, J., \& Buganza, J., (2009). La teoría del conocimiento transdisciplinar a partir del Manifiesto de Basarab Nicolescu. Fundamentos en Humanidades. Universidad Nacional de San Luis - Argentina, Año X, I(19), 43-55.

Sauvé, S., Bernard, S., \& Sloan, P., (2016). Environmental sciences, sustainable development and circular economy: Alternative concepts for trans-disciplinary research. Environmental Development, 17(1), 48-56. https://doi.org/10.1016/j.envdev.2015.09.002

Vandermeulen, V., Van Huylenbroeck, G., (2008). Designing trans-disciplinary research to support policy formulation for sustainable agricultural development. Ecological Economics, 67(1), 352-361. https://doi.org/10.1016/j.ecolecon.2008.05.016

\section{Copyright Disclaimer}

Copyright for this article is retained by the author(s), with first publication rights granted to the journal.

This is an open-access article distributed under the terms and conditions of the Creative Commons Attribution license (http://creativecommons.org/licenses/by/3.0/). 